UDC (07) 621.7,621.8

DOI: $10.25140 / 2411-5363-2021-2(24)-38-42$

\title{
Peter Tuleja
}

\section{TEACHING METHODOLOGY FOR ELECTRO-PNEUMATIC SYSTEMS MODIFIED BY PANDEMIC SITUATION}

The article describes the modification of the established form of the teaching process dedicated to fluid mechanisms and the control of such mechanisms. It deals with the methodology of preparation and implementation of teaching units in the past performed as practical exercises. By modifying it, it was possible to provide teaching units in the form of Internet transmission via the Microsoft application environment so that students could gain practical experience despite the fact that they completed the teaching in the distance form. In the end, the problems that will need to be solved in the future are outlined, and the trend that we would like to continue is outlined either.

The article is a publication of methodical character.

Keywords: methodics; training; electro-pneumatics; control; controller; programming; modification.

Fig.: 7. Table: 1. References: 3 .

Urgency of the research. The situation caused by the coronavirus pandemic "expelled" university students from classrooms and laboratories. This natural environment for knowledge transfer has been replaced by a virtual environment of computer applications enabling distance learning. However, this form strongly disrupted the possibilities of practical training of our students. It was necessary to find suitable forms to at least partially preserve the original possibilities provided by the equipment of our laboratories.

Target setting, actual researches and issues analysis. Such an experiment took place in the teaching of some subjects focused on automation in combination with pneumatic drives and electropneumatic control elements. The original concept described [2] had to be replaced by a modification that would allow remote access to the student in solving the assigned task. We returned to the methodology, the concept of which was proposed [1], but due to shortcomings in the technical equipment and in the possibility of testing, it was not implemented. It consisted of connecting the teaching space (e.g. laboratory) with the student in the form of network transmission (Fig. 1).

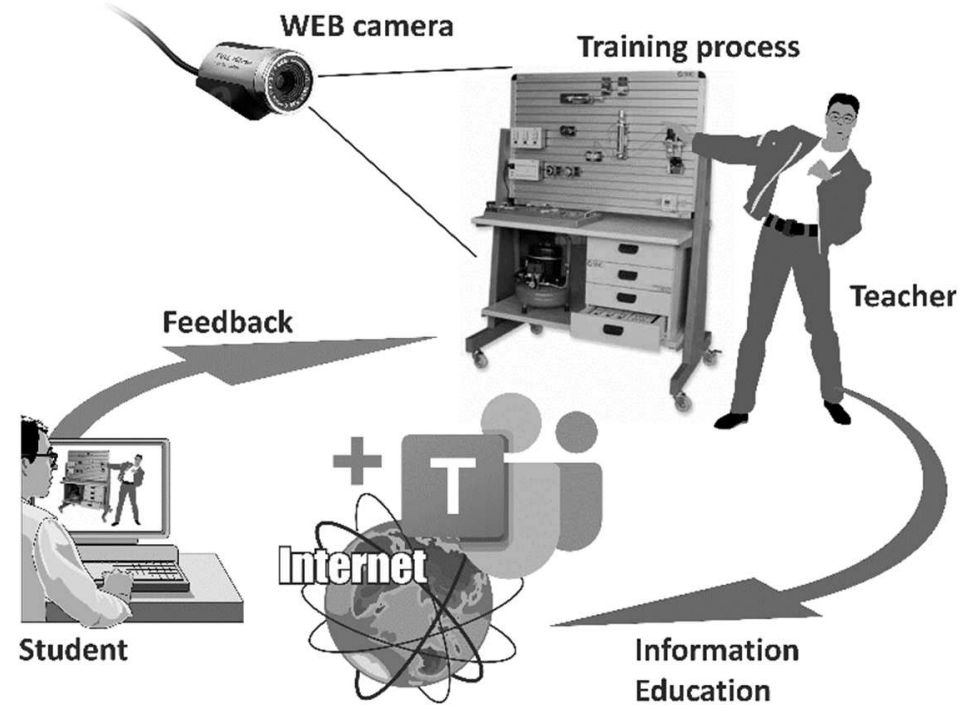

Fig. 1. Model of remote access within education

A continuously modified simulator was available, which was made back in 2018 by our graduate [3] as a diploma project (Fig. 2). 

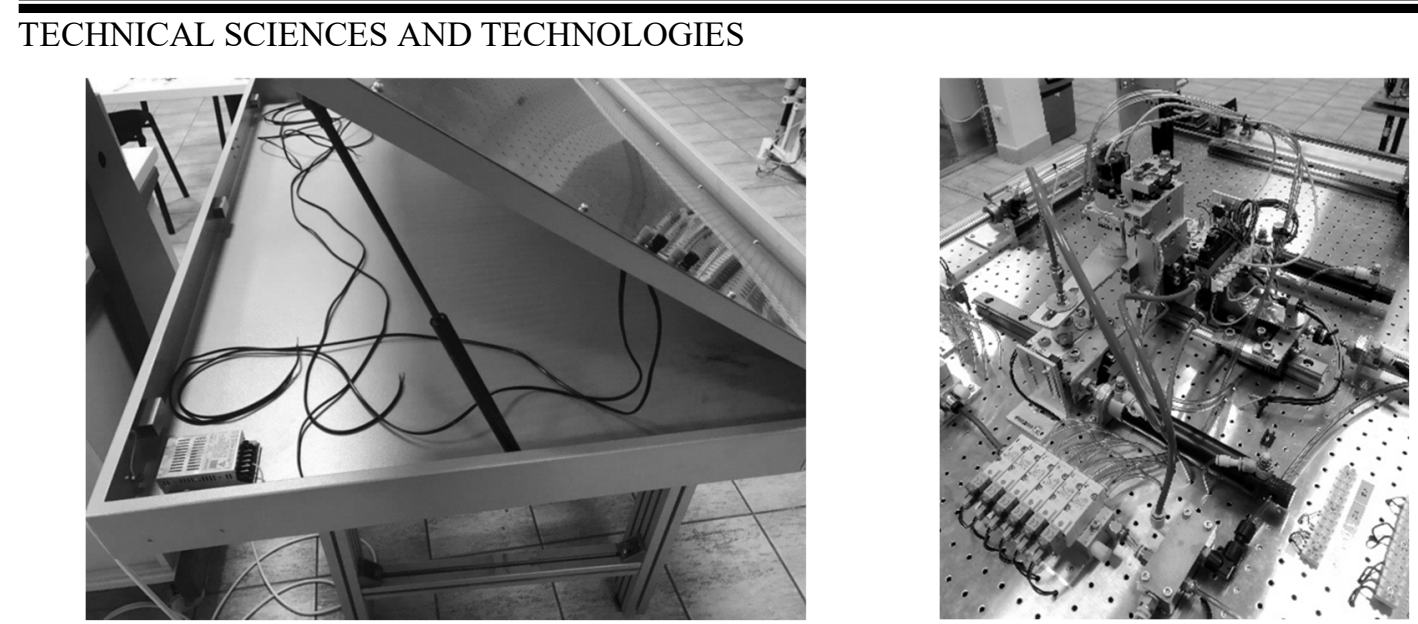

Fig. 2. Training stand

A Full HD WEB camera (Ausdom AW615) was purchased from the institute's funds (Fig. 3).

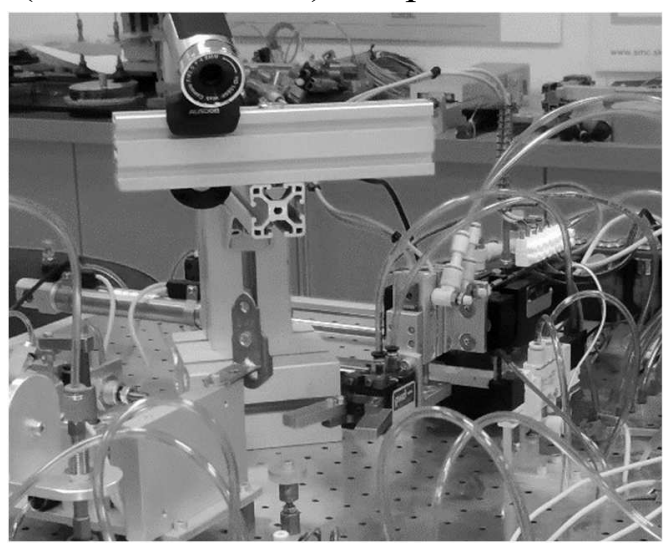

Fig. 3. WEB camera set to capture the workplace

The statement of basic materials. The events on the stand mediated by capturing the situation with a WEB camera were captured via the licensed Microsoft TEAMs platform. During the lessons, the students had information approximately as shown in Fig. 4.

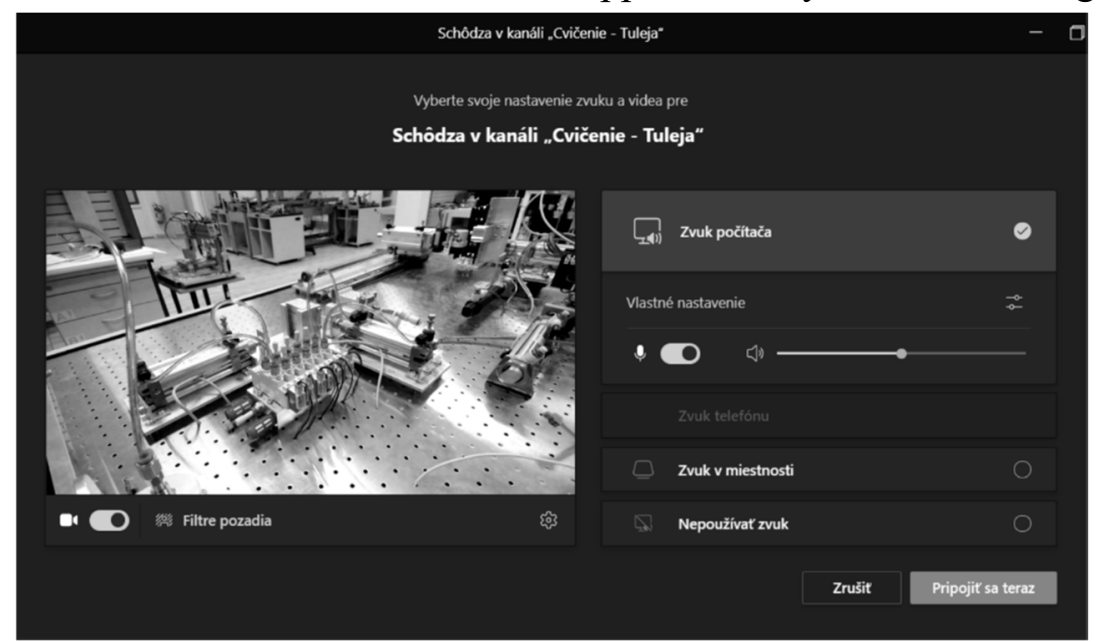

Fig. 4. Microsoft TEAMs application environment

Despite the imperfections of image transmission caused by the insufficient permeability of the Internet, students were able to watch what was happening in real time in the area of the training workplace. As the teaching units implemented in such an arrangement met with a positive response, we decided to continue the project. We re-arranged the simulator environment and supplemented it with a suitable description of individual "workplaces" (Table 1). 
Table 1 - Workplaces and their components

\begin{tabular}{|c|c|c|}
\hline & Name of workplace & Used components and their manufacturers \\
\hline 1. & $\begin{array}{l}\text { The mechanism of three degrees of } \\
\text { freedom }\end{array}$ & $\begin{array}{l}- \text { 1x CYLINDER SMC CD85N20-100-B + FLOATING JOINT } \\
\text { JA20-8-125 } \\
\text { - } 1 \text { x GRIPPER phd 19012-5-5002 } \\
\text { - } 1 \text { x SLIDE SMC MXH10-15 } \\
\text { - 1x SLIDE phd SA047X50 106 } \\
-\quad \text { 1x CLAMP SMC MXB12-10R }\end{array}$ \\
\hline 2. & $\begin{array}{l}\text { Mechanism (originally) for } \\
\text { SIEMENS S7 }\end{array}$ & $\begin{array}{l}-1 \text { 1x CYLINDER SMC CD85N20-100-B + FLOATING JOINT } \\
\text { JA20-8-125 } \\
-\quad \text { 1x SMC PRECISION SLIDE MXS16-75AS } \\
- \text { 1x SMC VANE ROTARY MOTOR MDSUB20-180S1 } \\
-\quad \text { 1x SMC EJECTOR } \\
-\quad \text { 1x VACUUM SWITCH SMC ZSE1-00-55L } \\
-\quad \text { 2x CYLINDER HOERBIGER RD 1025/100 }\end{array}$ \\
\hline 3. & Cylinder with continuous piston rod & $\begin{array}{ll}- & \text { 1x CYLINDER SMC CP96SDB40-150W }\end{array}$ \\
\hline 4. & Mechanism with trapezoidal screw & $\begin{array}{ll}- & \text { 1x SLIDE SMC MGPM25TF-100Z } \\
- & \text { 1x SLIDE phd } \\
- & \text { 1x GRIPPER SMC MHQJ2-16D } \\
\end{array}$ \\
\hline 5. & BOSCH-Rexroth workplace & - 2x CYLINDER Rexroth $082234900220718 ø 25$, H: 50 \\
\hline 6. & Mechanism with a suction cup & $\begin{array}{l}- \text { 1x SMC MY1B16G-100 } \\
- \text { 1x SUCTION CUP SMC }\end{array}$ \\
\hline 7. & Component separator & - ODDEL'OVAČ SÚČIASTOK SMC MIV12-12D \\
\hline 8. & Cylinder with brake & - COMPAST CYLINDER with BRAKE RDLQB40-100--M9B \\
\hline 9. & Traffic light - working with lights & - 4-farebný „semafor“ \\
\hline 10. & $\begin{array}{l}\text { Lifting mechanism ( } 2 \text { cylinders: } \\
\text { stroke + stopper) }\end{array}$ & $\begin{array}{l}\text { - 1x mini CYLINDER AiR AURRi (SMC type) CDJ2-16-150 } \\
\text { - } 1 \mathrm{x} \text { CYLINDER SMC CQ2B25-10D }\end{array}$ \\
\hline
\end{tabular}

This report (Table 1) is supplemented by the following documents:

1. Task entry sheet, fig. 5

2. Description of individual components;

3. Designation of individual signal elements and assignment of input addresses in the PLC;

4. Assignment of control elements (selectable) to PLC outputs

5. Datasheets of a specific actuator or valve;

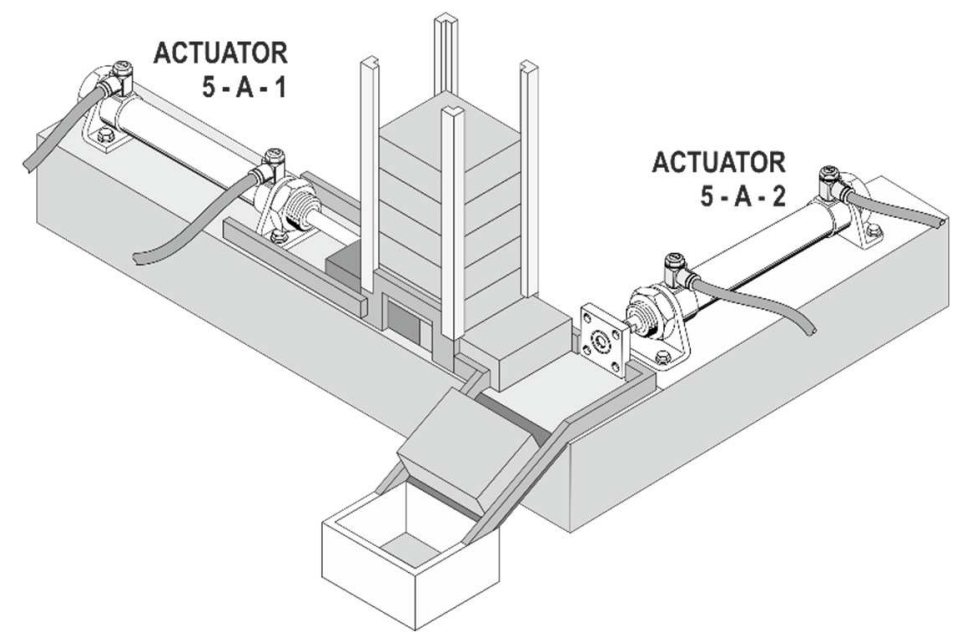

Fig. 5. Schematic representation of the task assignment

The components available on the training table are products from various manufacturers (SMC, HOERBIGER, MECMAN, Rexroth, phd Inc. etc.). The task of Fig. 5 is realized by a pair of drives Rexroth 082234900220718 ø25, H: 50 (Fig. 6). 

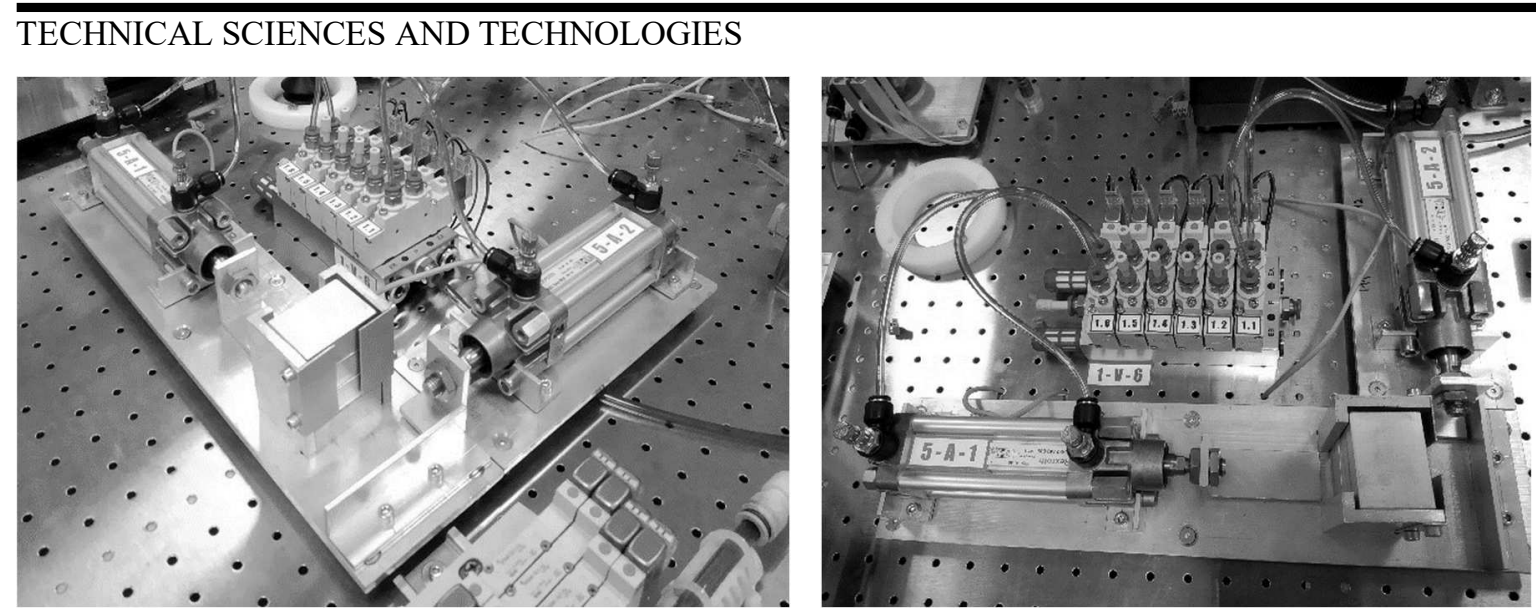

Fig. 6. BOSCH-Rexroth workplace (point 5 of table 1)

The individual cylinders had to be appropriately named (cylinder $5-\mathrm{A}-1$, cylinder $5-\mathrm{A}$ - 2) so that they could be easily and unambiguously identifiable both in the task assignment process and during the video transmission itself. The same had to be done with the electropneumatic control elements (valves 1.6 and 1.1 on the valve island $1-\mathrm{V}-6$ ).

As part of the solution and with the accompanying commentary of the teacher, according to the assignment, students had to develop a management program to ensure the functions and activities of the "workplace".

Since the system SIEMENS LOGO! 0BA6 in special modification [3] (Fig. 7) is applied as a managing controller, students can download and install a demo version of the LOGO! Soft Control programming environment free of charge from the manufacturer's website of this controller and with the help of the manual and the teacher's explanation will create a solution program. They upload it to the specified folder in the MS TEAMs environment, from where the teacher uploads it to the controller unit. The student monitors the behavior of their own program via video transmission and evaluates its functionality together with the teacher. If necessary, the teacher provides an explanation of the improper behavior of the program.

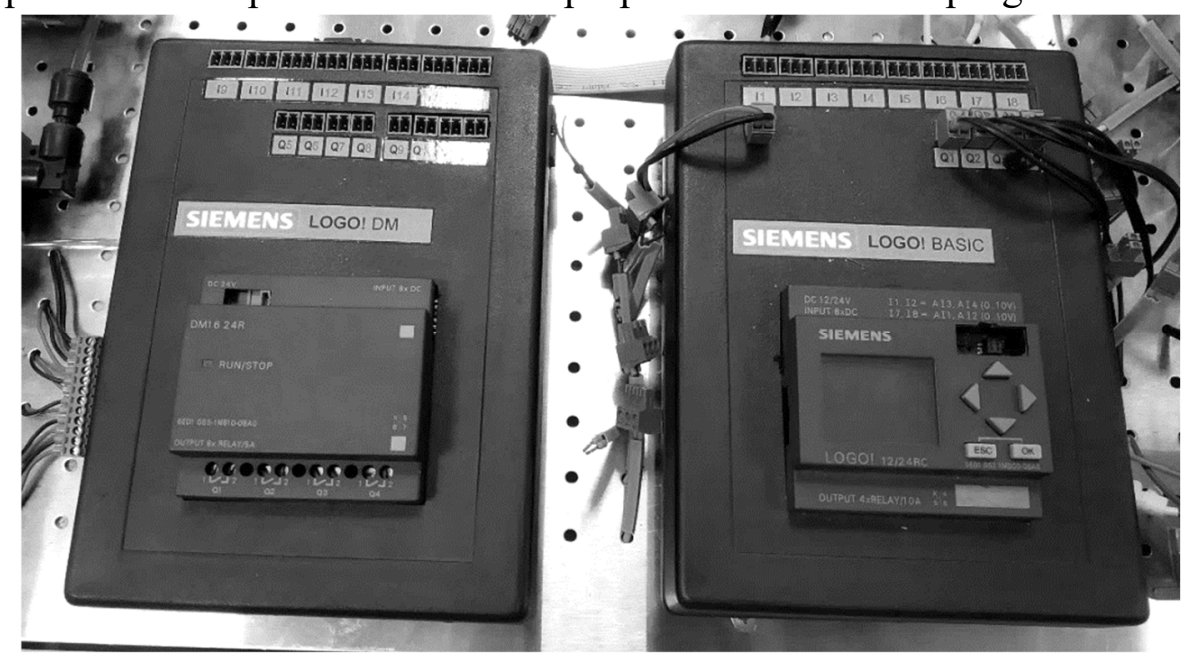

Fig. 7. SIEMENS LOGO! controller in special modification

There are also other separate mechanisms controlled via PLC SIEMENS LOGO!:

1. $2^{\circ}$ mechanism with gripper and parts magazine

2. The "Flying Ball" mechanism

3. 4-finger hand mechanism

4. Mechanism with $C D$ carriers

5. Mechanism with $3^{\circ}$ freedom

6. Mechanism with magnetic gripper

7. Table tennis ball "launcher" 
It is obvious that all modifications in the layout of the training table will be applicable in the full-time form of teaching directly in the laboratory after the end of the restrictions caused by the pandemic.

Conclusion. The mentioned modification of the methodical teaching procedure in the Laboratory of Pneumatic Mechanisms is constantly in the process of construction. In the future (depending on financial possibilities), we would like to expand this simulator with other models of workplaces, but also to create a variant training solution with several types of controllers.

Acknowledgements. This article was created thanks to the KEGA project support: 010TUKE-4/2020 Implementation of new knowledge and innovative approaches to the process of teaching robotics in line with Industry 4 and KEGA project support: 004TUKE-4/2021 Development of innovative teaching materials for learning multi-agent robotics.

\section{References}

1. Tuleja, P., Mamontov, P. (2018). Application of industrial pneumatic components in the educational process. Technical sciences and technologies, 3 (13), 68-73. http://tst.stu.cn.ua/articles/1548250674891.pdf.

2. Вархола, М., Тулея: П.: Методическая модель подготовки студентов для применения на практике автоматизированных устройств работающих на основе сжатого воздуха. Збірник наукових пращь: педагогічна секиія, Кам'янець-Подільський наиіональний університет імені Івана Огієнка. 2010. С. 188-191.

3. Mamontov, P., Tuleja, P.: Návrh a realizácia stendu pre výučbu pneumatických mechanizmov, Diplomová práca, Technická univerzita v Košiciach, Strojnícka fakulta, Košice, 2018, 58 str. (in Slovak).

УДК (07)621.7,621.8

\section{Петер Тулея}

\section{МЕТОДИКА ВИВЧЕННЯ ЕЛЕКТРОПНЕВМАТИЧНИХ СИСТЕМ, МОДИФІКОВАНА ПАНДЕМІЧНОЮ СИТУАЦІЕЮ}

У статті представлено модифікований варіант навчального робочого місия з урахуванням протиепідемічних обмежень в умовах пандемії коронавірусної інфекиії СОVID19. Актуальність розробки трунтується на тому, щзо пандемічна ситуаиія далека від завершення. Ймовірно, попереду ще кілька хвиль, у ході яких ией проєкт буде задіяний.

У статті описана методична прочедура вирішення «пандемічного» варіанта навчального робочого місия з електропневматичними компонентами, який раніше вже успішно використовувався.

Аналіз останніх досліджень і публікацій показав, щзо хоча окремі виробники пневматичних компонентів досліджують ие питання, основна увага приділясться бізнесу, а не практичній, орієнтованій на споживача сфері застосування. Завданням роботи є не доскональна деталізація конструктивного рішення, а ескізний проєкт із демонстраиією його можливостей. Основна мета статті - надати інформацію про те, як забезпечити набуття практичних навичок в умовах дистаниійного навчання.

Описане технічне рімення і методика проведення практичних занять у цій галузі в умовах карантинних обмежень нададуть методичне керівничтво для створення подібних освітніх удосконалених рімень, тим самим допомагаючи підвищити якість підготовки нового покоління інженерів в умовах триваючої пандемії.

Представлена в роботі модифікована методика вивчення елементів електропневматичних систем в лабораторії пневматичних механізмів постійно перебуває в стадії розробки. У майбутньому (в залежності від фінансових можливостей) ставиться за мету розширення можливостей цьього тренажера, доповнюючи його іниими моделями робочих місиь. Також передбачено можливість створення варіанта навчального робочого місия з декількома типами контролерів.

Стаття є публікачією методичного характеру.

Ключові слова: методика; навчання; електропневматика; контроль; контролер; програмування; модифікація. Рис.: 7. Табл.: 1. Бібл.: 3.

Tuleja Peter - Eng., PhD, Assistant Professor, Technical University of Kosice, Faculty of Mechanical Engineering, Institute of Automation, Mechatronics, Robotics and Production Systems, Department of Production Systems and Robotics, Komenskeho Park 8, 04200 Kosice, Slovakia.

E-mail: peter.tuleja@tuke.sk

Scopus Author ID: 55570858300

\footnotetext{
Tuleja, P. (2021). Teaching methodology for electro-pneumatic systems modified by pandemic situation. Technical sciences and technologies, (2(24)), 38-42.
} 